\title{
Overview Of Criminology And Criminal Law Concerning The Criminal Act Of Abuse Performed By Parents Against This Bird Children (Study Of The Decision Of The State Court Tulung Agung Number 179/Pid.Sus/2012/PN. Ta)
}

\section{Maya Etrisna Mendrofa}

Sumatera University Faculty Of Law. E-mail: mayamendrofa@gmail.com

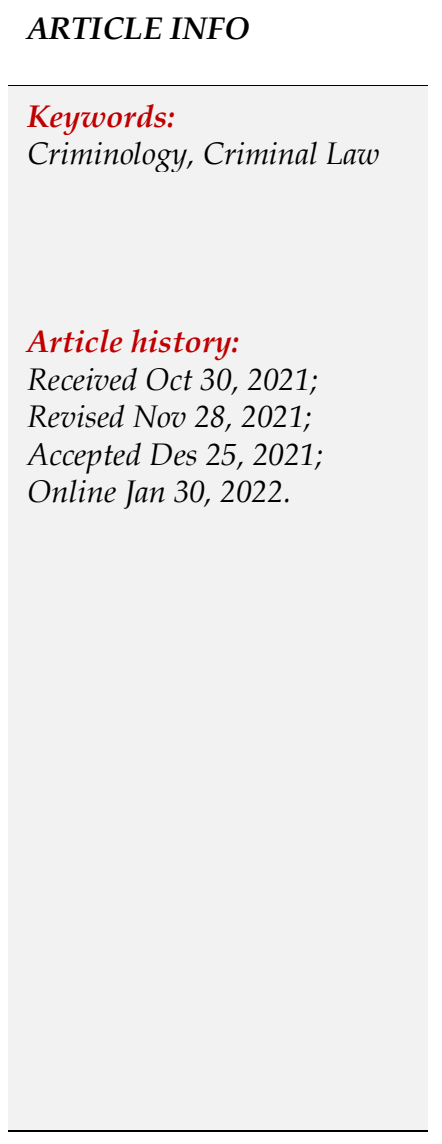

\begin{abstract}
The Indonesian nation is known as a nation that loves children. Turns out this is just a myth. Many cases of physical violence or cases of child abuse in their own families are not taken seriously by law enforcement. This situation causes the dark number to be high because it is not reported. Though the impact of the perpetrator tends to damage the mental even the victim is mentally retarded. This is certainly the main idea and responsibility of the government and society as observers of the nation's children who are the next generation of the nation's ideals. Why abuse among children is increasing, how does our positive law issue policies to deal with cases of violence experienced by children, and what other efforts can be taken to overcome violence experienced by children into the formulation of the problem of this thesis. The approach method used in this research is normative juridical, which is a deductive research that begins with an analysis of the articles in the laws and regulations governing thesis problems. Normative nature means legal research that aims to obtain normative knowledge about the relationship between one regulation and another and its application in practice (decision study). The factors that cause the occurrence of criminal acts of abuse or violence against children by their own parents are classified into two parts, namely internal factors and external factors. In dealing with cases of abuse experienced by children, it consists of criminal law policies such as the application of criminal sanctions and the application of legal protection for children. In addition, in tackling the crime of child abuse, there are several efforts that can be taken, namely preventive efforts, repressive efforts and reformative efforts.
\end{abstract}

This is an open access article under the CC BY-NC license.

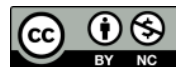

\section{Introduction}

In order to carry out the task of regulating and supervising banks, Bank Indonesia is given the authority to stipulate regulations and licenses for bank institutions and business activities as well as impose sanctions on banks in accordance with the prevailing laws and regulations.

In addition, the financial and banking crises that occurred in 1997-1998 have provided very valuable lessons on the importance of creating a framework for financial system stability where financial system stability is a series of processes and activities that begin with monitoring, identifying the possibility of a crisis occurring. , to the prevention of the crisis. The aspect of monitoring and identifying crises is one of the important pillars in maintaining financial system 
stability because preventive and anticipatory measures are seen as cheaper steps than crisis resolution. Basically, the establishment of this LPS was carried out only as an effort to provide protection against two risks, namely irrational run against banks and systemic risk. In running their business, banks usually only leave a small portion of the deposits they receive in case of withdrawal of funds by customers. Meanwhile, the largest part of the existing savings is allocated for lending. This situation will cause banks to be unable to meet requests in large quantities immediately for customer deposits they manage, in the event of sudden and large withdrawals. This limitation in the provision of cash funds is due to the fact that the bank cannot immediately withdraw the loan that has been disbursed. If the bank is unable to fulfill the deposit withdrawal request by the customer, then the customer will usually panic and will close his account at the bank in question, even though the bank is actually healthy. Meanwhile, systemic risk occurs when the bankruptcy of a bank has a negative impact on other banks, thus destroying the largest segment of the banking system.

Therefore, IDIC is expected to be able to maintain public trust in the banking industry and to minimize the emergence of risks that will burden the state budget. In order to continue to increase public confidence in banking, the IDIC does not only act as an institution that will guarantee customer deposits at the bank, but the IDIC also plays an important role in maintaining the stability of the financial system in Indonesia.

It is not only LPS that play a role in maintaining financial system stability. If we look at the mandate of Article 34(1) of Law Number 23 of 1999 concerning Bank Indonesia, it is stated that: "The task of supervising banks will be carried out by an independent financial services sector supervisory agency, and established by law." If viewed from the contents of Article 34(1) above, it can be said that the Article emphasizes the supervisory agency to act as a supervisory board (supervisory board), and can issue provisions relating to the implementation of bank supervision tasks and coordinate with Bank Indonesia. The establishment of this supervisory agency is mandated to be established by law no later than December 30, 2010. Due to the increasing number of banks that have begun to emerge in Indonesia, plus problems in the financial sector, there will be a need for a higher and better professional institution. in supporting the performance of banks in Indonesia.

With the enactment of the Law on the Financial Services Authority (OJK) on November 22, 2011, the banking situation in Indonesia has entered a new phase. Regulation and supervision in the banking sector are no longer with Bank Indonesia but have been transferred to OJK as an independent institution with the functions, duties and authority to regulate, supervise, examine and investigate the financial services sector in Indonesia. Every bank operating in Indonesia is required to become a participant in the LPS and pay a loan premium. In the event that the bank is unable to continue its business, and its business license must be revoked, the IDIC will pay the deposit of each customer of the bank up to a certain amount. Unsecured deposits will be settled through the bank's liquidation process. This liquidation is a follow-up to the settlement of banks experiencing financial difficulties. IDIC takes action to settle or handle banks experiencing financial difficulties within the framework of an integrated, efficient, and effective working mechanism to create resilience in the Indonesian financial sector or known as the Indonesia Financial Safety Net (IFSN). IDIC together with the Minister of Finance, Bank Indonesia, and the Banking Supervisory Agency (LPP) became members of the Coordinating Committee until the formation of the LPP or OJK in accordance with the mandate of Law no. 3 of 2004, the function of the LPP is still carried out by Bank Indonesia.

\section{Method}

The research method used in this research is normative juridical, which is a deductive research that begins with an analysis of the articles and laws and regulations governing the problems in the thesis. Normative nature means legal research that aims to obtain normative knowledge 
about the relationship between one regulation and another and its application in practice (study of decisions).

The data collection technique carried out by the researcher is a data collection technique through library research, where the researcher obtains data by collecting and discussing research materials, namely primary legal materials, secondary legal materials and tertiary legal materials for this study.

\section{Analysis And Results}

\subsection{Factors That Cause The Criminal Action Of Massage Against Children By Parents}

\section{a. Mazhab - Schools About The Causes Of Crime}

1) School of Sociology

In carrying out their scientific investigations about crime and about the symptoms of pathology - social, sociologists use the statistical method. Statistics are mass observations using numbers while also pushing hard for the advancement of social science. Since the 17th century, statistics have been used, such as the sociologist J. Graunt using statistics to make a list of the numbers concerned, finding that the number of deaths and birth rates from year to year always returns very regularly. However, the use of statistical science did not develop because at the beginning there was no theoretical basis, generally only based on experience. In addition, the materials recorded were not reliable, because they were only based on estimates, not based on calculations. In the end, statistical science progressed and changed drastically through Quetelet (1796 - 1874), a biologist and sociologist who made statistics a definite scientific method and created the foundations of practical statistics. Quetlet based on criminal statistics which is used as a tool in criminal sociology proves for the first time that crime is a social fact, seeing that crimes such as murders that are planned every year are always the same and the way they are done is the same.

\section{a) Criminal Statistics as a Static Method}

After several years of crime statistics in France began to be published, several authors began to collect relevant materials for processing, including materials on sex and age data related to crime. Also the collection of crime geography data based on the attached maps, it is seen that in the richest province there are the most crimes against property rights due to the unequal distribution of wealth causing a lot of poverty. Quetelet as a static person, assumes that humans are powerless against the existence of evil in the world as natural conditions cannot be avoided. He also investigated influence ; the possibility of doing evil as seen from education, work, poverty, climate.

\section{b) Criminal Statistics as a Dynamic Method}

Quetelet firmly admits that there is a dynamic element in crime. Indeed, in his investigation, which lasted only a few years, there were no major changes in the social field and there were visible elements that were fixed. However, if we look at the results of several countries' research over the years, it can be seen that there have been major changes in crime given that major changes have taken place in society at the same time. For example, the figure LM Christophe $(1791$ - 1888) said that in England there was a relationship between the development (destruction) of industry and the increase in poverty which led to an increase in the number of crimes. 
2) Environmental School

This school was pioneered by medical experts in France who opposed Lombroso's teachings on anthropological crimes from the 19th century. They all follow the lines given by J. Lamarck, E. Geoffroy and L. Pasteur which emphasize the meaning of the environment as the source of all kinds of creatures and diseases that arise. This school is mostly more advanced environmental theory by opposing the teaching that says that evil exists from birth.The leading figure was A. Lacassagne (1843 - 1924) a professor in judicial medicine at the International Criminal College. He challenged Lombroso's hypothesis and formulated the teachings of the environmental school as follows: "The most important thing is the social situation around us. By a modern comparison where the social situation around us is likened to a seed for evil, the germ is the one who acquires it, an element will have meaning if it finds the seed in which it thrives."

3) School of Bio - Sociology

The Bio-Sociology School or this combined school was initiated by Enrico Ferri who explained that the combination of anthropological schools and environmental conditions was the cause of crime. The formula reads: "Every crime is the result of the elements contained in the individual, society and physical condition."134 What is meant by the elements contained in the individual are the elements as described by Lombroso.

4) Spiritualist School (Religion)

Among the schools of criminology that have their own position, it is this school that used to look for the most important cause of crime in a person's non-religion. Then this school underwent various changes and subtleties which at this time is more precisely called the neo-spiritualist school, which when compared to the previous schools, this flow is more likely to attach importance to the spiritual element in the occurrence of crimes. Some figures belonging to the old school such as: M. De. Baets (1863-1931) a priest in Belgium said the reduced influence of religion was one of the most important reasons for the increase in crime. Another figure, FAK Krauss (1843 - 1917) thought, the increasingly widespread view of the lower layers of society, alienation from God and a view of life and a view of the world which became an empty basis in terms of moral impulses, was a black basis where rottenness and crime thrive.

\section{b. Factors Caused Parents Of Massage By Parents On Children}

1) Causes of Child Abuse in the Family

The occurrence of child abuse in the family by the father or mother (parents) is caused by various factors that influence it. According to Richard J. Gelles, the abuse that is often experienced by children in the family occurs due to a combination of various personal, social and cultural factors which include the inheritance of violence between generations, social stress, social isolation and involvement of the lower community and family structure.

2) The Inheritance of Violence Between Generations

Parents who are "talented" to abuse their children have certain characteristics such as having a violent childhood background, they are also used to receiving beatings and being raised by their parents' abuse. Many children learn violent behavior when they are mistreated by their parents and when they grow up they will tend to mistreat their children. Studies show that approximately 30 percent of children who are treated with violence become parents who act harshly on their children. Thus, violent behavior is 
inherited (transmitted) from generation to generation.

\section{3) Social Stress}

Stress caused by various social conditions increases the risk of violence against children in the family. These social conditions include: unemployment, illness, poor housing conditions, larger than average family size, the birth of a new baby, the presence of a disabled person at home and the death of a family member. Most of the reported cases of acts of physical abuse against children come from families living in poverty. Acts of violence against children also occur in middle and rich families, but the reported acts are more among poor families for several reasons. Alcohol and drug use among abusive parents may increase stress and stimulate violent behavior. Certain characteristics of children, such as mental weakness or physical developmental disabilities, also increase parental stress and increase the risk of violence.

4) Family Structure

Certain types of families have an increased risk of committing acts of physical violence against children. For example, single parents are more likely to commit acts of physical violence against children compared to intact parents. Because single-parent families usually earn less than other families, this can be said to be the cause of increased acts of violence against children. Families with chronic fights or abused wives have higher rates of child abuse than families without problems.

\section{5) Factors that come from within the child}

The occurrence of acts of domestic abuse is not only caused by factors contained in the parents or perpetrators but can also be triggered by the condition and behavior of the child. The condition of the child, for example: The child suffers from developmental disorders, suffers from chronic diseases, is caused by the child's dependence on the environment, the child has physical disabilities, mental retardation, behavior disorders, autism and children who carry out deviant behavior.

A clearer picture of the effects of acts of physical abuse on children can be seen in Moore's explanation who observed several cases of child victims of physical abuse. He revealed that these effects are so widespread and can generally be classified in several categories: some become negative and aggressive and easily frustrated, some become very passive and apathetic, some have no personality of their own, what they do all their life is only to fulfill their parents' wishes, unable to respect himself, the emergence of extraordinary hatred towards himself because he feels that he is the only one who is always guilty, causing torture against himself and this hatred of himself leads to acts of self-harm such as suicide and so on.

Maybe not many parents know that physical beatings cause emotional damage to children. As they get older, boys tend to become very aggressive and hostile towards others, while girls often regress and withdraw into their own fantasy world. However, the sadder effect is that girls then feel all the boys hurt (causing them to hate men), while the boys then believe that men have the right to beat their wives.

\subsection{Criminal Law Policy In Handling Criminal Acts Of Ministry Of Children In Household}

\section{a. The Understanding Of Criminal Law Policy}

Prof. Sudarto, SH, once put forward three meanings regarding criminal policy or politics, namely:

1) In a narrow sense, it is the overall principles and methods that form the basis of reactions to violations of the law in the form of crimes;

2) In a broad sense, it is the overall function of the law enforcement apparatus, including the 
workings of the courts and the police.

3) In the broadest sense (which he took from Jorgen Jepsen), is the overall policy, carried out through legislation and official bodies, which aims to enforce the central norms of society.

On another occasion, he put forward a brief definition, that criminal policy is "a rational effort of society in overcoming crime". Criminal policy is essentially an integral part of community protection efforts and efforts to achieve public welfare. Therefore, it can be said that the ultimate goal or main goal of criminal politics is "protection of society to achieve public welfare.

\section{b. Criminal Law Policy In Handling Criminal Acts Of Ministry Of Children In Household}

In terms of handling cases of children who are victims of criminal acts of domestic abuse, criminal law policy is an effort to implement criminal acts and apply protection for children. In addition to policies that use the means of criminal law, there are also non-criminal law policies consisting of efforts to prevent criminal law and efforts to influence public views on crime.

In criminal law, the losses suffered by children as victims of violence have not been concretely regulated. This means that criminal law provides protection to children as victims, more of an abstract protection or indirect protection, with the various formulations of criminal acts in the legislation. The system of sanctions and criminal responsibility is not focused on direct and concrete victim protection, but only indirect and abstract victim protection.

Crimes against the body committed intentionally (persecution) can be divided into six types, namely:

1) Ordinary persecution (Article 351)

2) Minor persecution (Article 352)

3) Premeditated persecution (Article 353)

4) Serious persecution (Article 354)

5) Premeditated serious abuse (Article 355)

6) Persecution in a way and against certain qualified persons which is incriminating (Article 356)

\section{c. Obstacles In Handling Cases Of Children Experienced In The Household}

Cases of violence experienced by children in their families are often difficult to reveal to the surface or are called iceberg phenomena. Even though the case has been identified, the investigation and judicial process is often very late. Barriers often arise during the investigation process because of the strong public perception that all acts of violence that occur within the household are personal matters so that they do not deserve to be interfered with by others. These difficulties are caused by several factors:

Rejection of the child as a victim itself. The victim does not report it because he is afraid of the consequences that will be received by the perpetrator (parents) because of the threat.

1) Manipulation of the perpetrator. Parents who commit criminal acts of abuse or other forms of physical violence against their children often deny accusations that they have committed violence. By reason of parents accusing children of lying or violations.

2) Families who experience cases consider that violence against children is a shameful disgrace if it is disclosed. The assumption that matters relating to family matters should not be interfered with by the community.

3) The wider community does not know clearly the "signs" in children who experience violence.

4) The occurrence of violent criminal acts such as abuse experienced by children is mostly known only by the perpetrators and victims, so that there is a lack of witnesses and evidence that meets articles 183 and 184 of the Criminal Procedure Code. In criminal acts 
that occur in the household sphere, the easiest evidence to obtain is the testimony of witnesses. However, regarding people who are witnesses in criminal acts, in general, they are blood relatives or by marriage from a straight line, relatives, husband or wife. Even though these people, based on article 168 of the Criminal Procedure Code, cannot be heard as witnesses. In the case of domestic violence to fulfill two pieces of evidence, the victim can be a witness and other evidence in the form of visum et repertum.

5) The delay in reporting from victims of cases of domestic violence will affect the level of difficulty for investigators in carrying out the investigation process, especially in collecting witnesses and evidence.

\subsection{Effort - Effort Countermeasures Action Criminal Children Massage}

After studying criminology in all its aspects, it has given us an understanding that essentially the purpose of studying knowledge about the causes of crime is to eradicate crime in order to create a safe and prosperous society. So the question arises, can this crime be eradicated and completely eliminated from society.

Criminologists argue that the prevention of crime can only be done by suppressing or reducing the growth and improvement of criminals so that they can return as good members of society.

Theoretically, crime prevention can be pursued in several ways, namely:

1) Preventive Effort

Preventive efforts are actions or efforts to prevent crimes committed long before the crime occurs, by involving cells of community organizations so that they can be empowered together in the context of monitoring groups or people who have the potential to commit crimes. This method can be done after knowing in advance the factors or causes of the crime.

\section{2) Repressive Effort}

Repressive efforts are carried out after the occurrence of a criminal event, namely law enforcement efforts against those involved in criminal acts. A person who has committed a crime will undergo an examination process which will eventually receive a verdict from a judge who, if found guilty, will be sentenced to exile from the community to a place called "Penitentiary". The provision of this punishment is an effort to restrain the perpetrators of crime so as not to interfere with the community environment in order to protect the peace of the community. So punishment in the form of a crime is something that must exist as a logical consequence of committing a crime because of course every crime must be punished.

However, there are still obstacles due to the limitations of criminal law in tackling crimes caused by:

a) The crime arises from other factors beyond the reach of criminal law

b) These limitations are also caused by the nature or nature of sanctions and the function of criminal law itself. The existing criminal sanctions are not drugs to overcome the causes of the disease but merely to overcome the symptoms or consequences of the disease.

c) Policies that are oriented to the punishment of perpetrators are very wrong because criminal sanctions are aimed at preventing people from committing crimes and not preventing the crime from happening.

d) The limitations of the types of criminal sanctions and the formulation of criminal sanctions that are rigid and imperative so that judges have no choice.

e) Weak supporting facilities. 


\section{3) Reform Effort}

Reform efforts are a form of effort to change back someone who has committed a crime and the crime will not be repeated if he has returned to society.

a) These reformative efforts include, among others:

b) Guidance in correctional institutions is in accordance with the concept of the institution, that the term prison sentence has shifted its emphasis to coaching. So in correctional institutions need activities:

c) Skills development;

d) Religious and moral development;

e) Mental and spiritual development;

f) Fertilization of physical and spiritual freshness.

4) Guidance outside the correctional institution:

a) Study in a job training place belonging to another industry or service (Job Training Center);

b) Carry out integrated supervision of the mental development or behavior of the perpetrators, especially those due to mental disorders;

c) Worship by praying in mosques, churches to increase the growth and development of the faith of the perpetrators.

d) Activating the perpetrators with various fields of activity such as sports and arts that aim to free the perpetrators from the mental anguish that haunts his mind as a result of his actions.

e) Granting parole.

\section{Conclusion}

The criminal act of child abuse that often occurs within the household where the perpetrator is none other than the child's own parents is caused by several factors that are classified into two major parts, namely internal factors, namely factors that come from within the perpetrator and the victim, then External factors that come from outside the perpetrator. The internal factors consist of:

Severe illness or mental disorder that the perpetrator (parents) may have or experience. This mental disorder or mental disorder arises due to pressures that attack the perpetrator so that the perpetrator loses consciousness and control himself and makes an outlet without realizing that his actions are wrong or right. This kind of thing often happens to parents who make their children the object of their instability. The things that cause this mental disorder in parents are influenced by things such as very concerning economic pressure, lack of good communication between family members, relatively low level of education, poor living environment, no sense of belonging. responsibilities between fellow members and parents who are not psychology cally mature.

The inheritance of violence between generations, where it is not uncommon for parents to commit violence to their children because the parents (father or mother) were raised with violence as well. Children whose childhood was taught by violence such as beatings, anger, and several other forms of physical abuse will imprint on them and will carry over into their adulthood. Therefore, when the child becomes a parent, unknowingly, the wrong treatment experienced as a child will be applied to their children later.

Social stress, sometimes parents can't put their emotions right and think that children are the most deserving of their every emotional outburst. Uncontrolled emotions in parents are 
influenced by the amount of stress they experience such as unemployment, illness, poor housing conditions, larger than average family size, the birth of a new baby, the presence of a disabled child at home and the death of a family member. So that parents, especially fathers, seek escapism by consuming alcohol which actually triggers violent treatment of children.

Family structure, not infrequently certain types of families can be the reason for the disharmony between parents and children. For example, parents who have been divorced or family problems. Such a situation can make parents no longer care about their children, children are left to find their own way of life and if children make mistakes, the parents do not hesitate to teach lessons because for them there is no use for kindness and harmony in the family. Factors that come from the child, such as the child has a disability, developmental disorder, or the child himself who deviates.

\section{References}

Arrashid, Chainur. 1988. Introduction psychology Criminal. Medan : Yani Corporation.

Bonger, W. 1981. Introduction to Criminal Psychology. Jakarta: Ghalia Indonesia.

Bonger, W. 1982. Introduction to Criminology. Jakarta: Ghalia Indonesia. Chazami, Adam. 2000. Crimes Against Body and Life. Jakarta : Raja Grafindo Persada.

Dirdjosisworo, Soedjono. 1985. Anthology of Criminology, Collection of Writings and Research Results. Bandung : ARMICO Dirdjosisworo, Soedjono., Simanjuntak, B. 1986. Doctrine - Doctrine of Criminology.

Gosita, Arif. 1989. Child Protection Issues. Jakarta: Pressindo Academy. Gultom, Maidin. 2012. Legal Protection Against Children and Women.

Huraera, Abu. 2012. Violence Against Children. Bandung: Scholarly Feel.

Kansil, C., Paladeng, Engelien., Musa. 2009. Criminal Acts in the National Law. Jakarta: Jala Permata Aksara.

Meliala, Syamsudin, A., Sumaryono, E. 1985. Child Crime An Overview of Psychology and Law. Yogyakarta : Liberty.

Nawawi, Barda. 2011. Anthology of Criminal Law. Semarang : Kencana Prenada Media Group.

Nugroho, Fentini. 2002. Exploratory Study on Violence Against Children in the Family. In the Journal of Sociology "Society". Jakarta: Gramedia Pustaka Utama.

Ridwan \& Adiwarman. 1994. Principles of Criminology. Medan : USU PRESS

Rusmil, Kusnandi. 2004. Child Abuse and Violence. Bandung : Paper "Handling Victims of Violence in Women and Children"

Sahetapy, JE, Reksodipuro, Marjono. 1982. Parados in Criminology.

Jakarta : Rajawali

Santoso, Topo., Eva, Zulfa. 2001. Criminology. Jakarta : Raja Grasindo Persada Setyowati, Irma. 1990.

Legal Aspects of Child Protection. Jakarta: Earth Literacy Simanjuntak, B. 1981. Several Aspects of Social Pathology. Bandung : ALUMNI Simanjuntak, Noach. 1984. Criminology. Bandung : Tarsito Siregar, Bisma., Hakim, Abdul., Suwantji., Gosita, Arif. 1986. Law and Rights 